\title{
Penggunaan Maple dalam Upaya Peningkatan Minat Siswa SMA dalam Pembelajaran Materi Integral
}

\author{
Sisilia Sylviani ${ }^{1}$, Fahmi Candra Permana ${ }^{2}$, Dian Rinjani ${ }^{3}$ \\ 1) Departemen Matematika, FMIPA, Unpad \\ Jl. Raya Bandung-Sumedang Km. 21, Jatinangor 45363 \\ Jl. Raya Cibiru Km 15 Bandung 40393 \\ Email: sisilia.sylviani@unpad.ac.id \\ 2,3) Program Studi Pendidikan Multimedia, Kampus UPI di Cibiru, \\ Universitas Pendidikan Indonesia \\ Jl. Raya Cibiru Km 15 Bandung 40393 \\ Email: 2)fahmi.candrap@upi.edu, 3)dianrinjani@upi.edu
}

\begin{abstract}
ABSTRAK
Integral merupakan salah satu materi yang dipelajari oleh siswa SMA. Materi tersebut merupakan salah satu materi yang sering dipandang cukup sulit untuk dipahami oleh siswa. Siswa juga sering mengalami kendala dalam memahami langkah-langkah pencarian integral dari suatu fungsi. Oleh karena itu, sebagai upaya meningkatkan minat siswa terhadap materi tersebut, dalam paper ini dibahas penggunaan Maple sebagai media pembelajaran matematika yang dapat digunakan dalam rangka membantu siswa SMA dalam memahami materi integral. Maple merupakan sebuah perangkat lunak yang canggih yang dapat digunakan untuk menganalisis, mengeksplorasi, memvisualisasi, serta menyelasaikan berbagai masalah matematika. Dengan Maple, siswa dapat melihat visualisasi dari konsep integral. Dengan melihat visualisasinya, diharapkan siswa dapat lebih tertarik pada pembelajaran matematika, khususnya materi integral.
\end{abstract}

Kata kunci: integral, maple, pembelajaran

\section{ABSTRACT}

Integral is one of the materials studied by high school students. The material is one material that is often considered quite difficult for students to understand. Students also often experience obstacles in understanding the integral of a function. Therefore, as an effort to increase students' interest in the material, this paper discusses the use of Maple as a medium for learning mathematics that can be used in order to help high school students understand integral material. Maple is a sophisticated software that can be used to analyze, explore, visualize, and solve various mathematical problems. With Maple, students can see visualizations of integral concepts. By seeing the visualization, students are expected to be more interested in learning mathematics, especially integral material.

Keywords: integral, learning, maple

\section{Pendahuluan}

Matematika telah lama dikenal oleh siswa sebagai mata pelajaran yang abstrak dan sulit. Cara yang masih sering dilakukan adalah guru menjelaskan secara teori kemudian memberikan latihan-latihan soal. Namun, dengan cara tersebut hal yang sering juga terjadi adalah siswa kurang dapat memahami konsep yang diberikan oleh guru serta cenderung bosan. Dengan demikian hal tersebut menurunkan minat atau ketertarikan siswa dalam memahami matematika. Menurut Hui Xu (2016), justru hal seharusnya dilakukan untuk meningkatkan minat atau pemahaman siswa terhadap matematika adalah dengan memfokuskan dalam melatif cara berpikir kreatif daripada hanya sekedar memindahkan pengetahuan-pengetahuan matematika dasar kepada mereka. Sehingga, di kelas Guru tidak hanya menjelaskan detil dari konsep-konsep dan teori-teori matematika, tetapi juga perlu untuk menuntun siswa untuk dapat melakukan observasi dan berpikir tentang hal-hal dalam sudut matematika. Guru juga perlu mengajarkan siswa untuk dapat membuat pertanyaan, membuat dugaan, serta mengeksplorasi dunia matematika.

Banyak penelitian telah dilakukan dalam rangka mengembangkan media pembelajaran matematika dalam rangka melatih kreativitas siswa dalam berpikir matematika. Media yang digunakan pun beragam. Namun, seiring dengan perkembangan jaman, saat ini hal yang sedang menjadi trend adalah pengunaan teknologi informasi di berbagai bidang. Sebagai contoh, Permana (2019) melakukan penelitian terkait penggunaan 
teknologi informasi terkait pendeteksian golongan darah berdasarkan konsep kepercayaan rakyat jepang. Bahkan dalam hal pengembangan media pembelajaran, beberapa peneliti juga telah melakukan hal tersebut diantaranya adalah T. M. Wasfy (2006) yang menggunakan system perangkat lunak yang berbasis web yang bernama LEA (Learning Environments Agent). M. A. Abánades et al. (2011) yang meggunakan perangkat lunak tidak berbayar Geogebra dikombinasikan dengan Sage, suatu perangkat lunak tidak berbayar yang didesain untuk komputasi Aljabar. Kemudian terdapat V. Thakkar et al. (2012) yang membuat suatu lingkungan interaktif dengan perangkat lunak animasi 3D dan perangkat keras untuk mendeteksi gestur. Saat ini terdapat beberapa perangkat lunak yang didesain khusus untuk komputasi matematika yang cocok digunakan untuk kalangan siswa SMA. Perangkat-perangkat lunak tersebut di antaranya adalah Maple, Mathematica, MATLAB, dan ActiveMath. Oleh karena itu, dalam paper ini, media yang akan digunakan adalah software Maple. Software Maple merupakan sebuah perangkat lunak yang canggih yang dapat digunakan untuk menganalisis, mengeksplorasi, memvisualisasi, serta menyelasaikan berbagai masalah matematika.

Maple adalah sistem komputer komersial yang dikembangkan dan dijual secara komersial oleh Maplesoft, sebuah perusahaan perangkat lunak yang berbasis di Waterloo, Ontario, Kanada. Versi utama saat ini adalah versi 2015, yang dirilis pada bulan Maret 2015. Ini pertama kali dikembangkan pada tahun 1980 oleh Grup Komputasi Simbolik di Universitas Waterloo. Pengguna dapat memasukkan matematika dalam notasi matematika tradisional. Antarmuka pengguna khusus juga dapat dibuat.

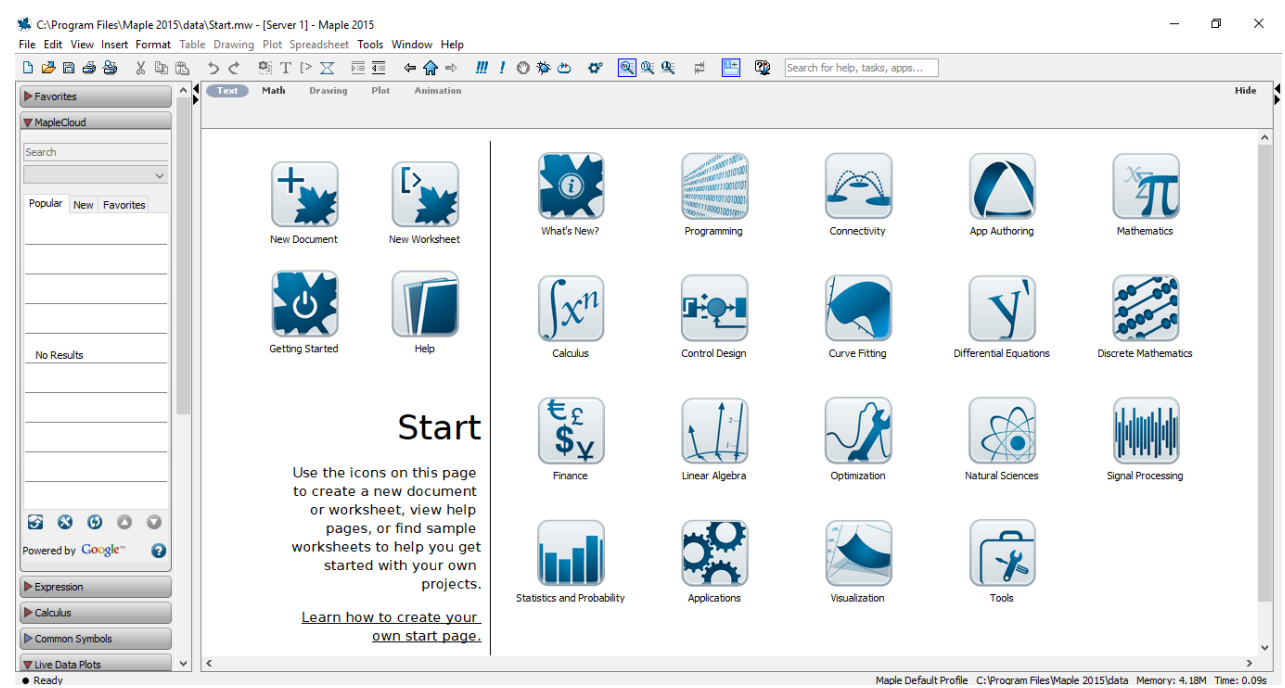

Gambar 1. Antarmuka pengguna Maple 2015

Versi terbatas pertama dirilis pada Desember 1980 dan didemonstrasikan untuk pertama kalinya di konferensi pada tahun 1982.

\section{Metode Penelitian}

Metodologi penelitian yang digunakan adalah studi literatur dari berbagai sumber baik buku-buku ataupun jurnaljurna. Literatur-literatur tersebut digunakan sebagai bahan penyusunan latihan terstruktur yang dapat digunakan untuk siswa dalam mengembangkan kreatifitas mareka dalam bermatematika. Dalam penelitian ini juga digunakan bantuan software maple sebagai alat bantu dalam menyusun media pembelajaran.

\section{Hasil dan Pembahasan}

Dalam pembelajaran materi integral di kelas, siswa pada umumnya mengalami kesulitan dalam memahami konsep integral. Salah satunya adalah bagaimana metode atau Teknik dalam pencarian nilai integral dari suatu fungsi. Hal yang pertama dapat dilakukan oleh guru setelah mengenalkan konsep serta contoh integral secara manual adalah dengan mengaplikasikan contoh pencarian nilai integral tersebut dengan menggunakan Maple. Fasilitas yang dapat digunakan adalah dengan "Tutor" yang ada pada Maple. Fasilitas terebut dapat ditemukan dengan memilih Tools pada toolbar, kemuadian pilih Tutor, kemudian pilih Calculus: Single Variable, dan yang terakhir karena konsep yang akan dibahas adalah integral, maka pilih Integration method. Untuk lebih jelasnya perhatikan gambari di bawah ini. 


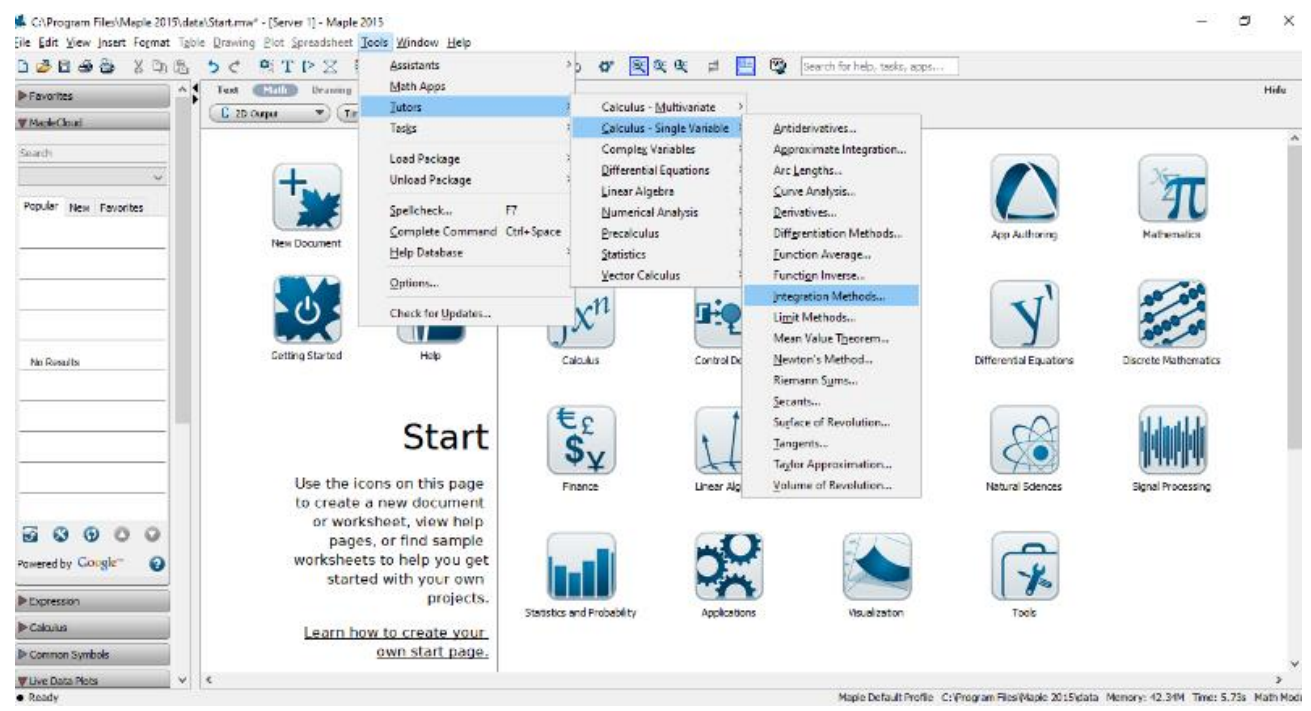

Gambar 2. Penggunaan tools Tutor pada Maple

Sebagai contoh, misalkan fungsi $f(x)=x\left(x^{2}+4 x+5\right)$. Setelah siswa diberikan pengetahuan secara konseptual bagaimana mencari nilai integral dari fungsi tersebut,maka untuk menambah pemahaman siswa tentang bagaimana mencari nilai integral tersebut, siswa diminta untuk menginputkan fungsi tersebut pada aplikasi maple yang telah dipilih tadi. Siswa menginputkan fungsi tersebut pada kotak "Function". Setelah itu karena fungsi tersebut dalam variabel x, maka pada kotak" variable" ketikan "x". langkah selanjutnya karena yang dicari adalah integral tak tentu, maka tinggal klik "start" kemudian klik "All Steps". Hasil yang akan keluar dapat dilihat pada Gambar 3.

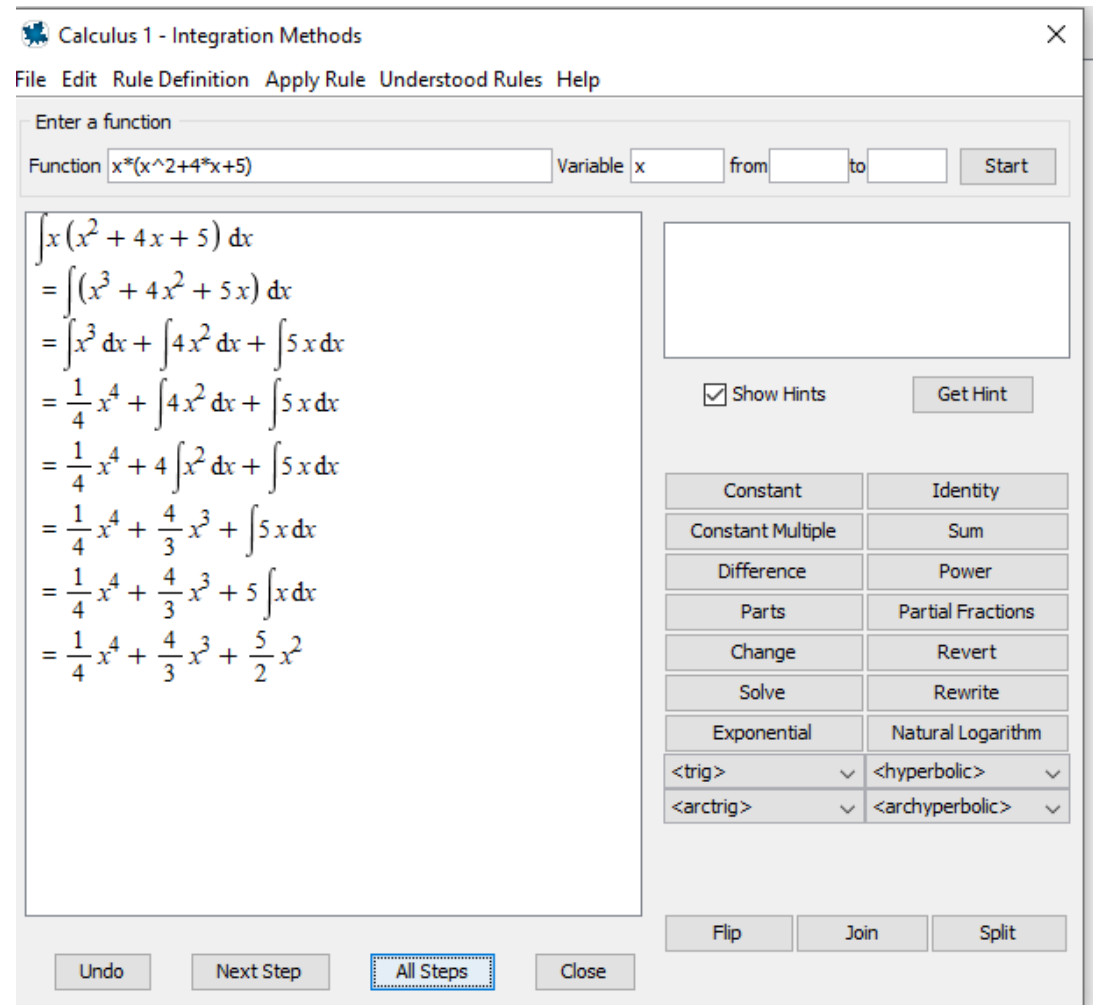

Gambar 3. tampilan hasil pencarian integral $f(x)=x\left(x^{2}+4 x+5\right)$

Berdasarkan gambar 3 terlihat bahwa maple tidak hanya memberikan output hasil integral dari fungsi tersebut, tetapi juga langkah-langkah pengerjaanya secara cukup detil. Apabila kita menginginkan hasil yang muncul adalah per langkah, maka setelah klik tombol "start", hal yang selanjutnya dilakukan adalah klik 
tombol "Next Step" berulang kali hingga hasil akhir dari integral tersebut dimunculkan oleh Maple. Gambar 4 berikut ini menunjukkan hal tersebut.

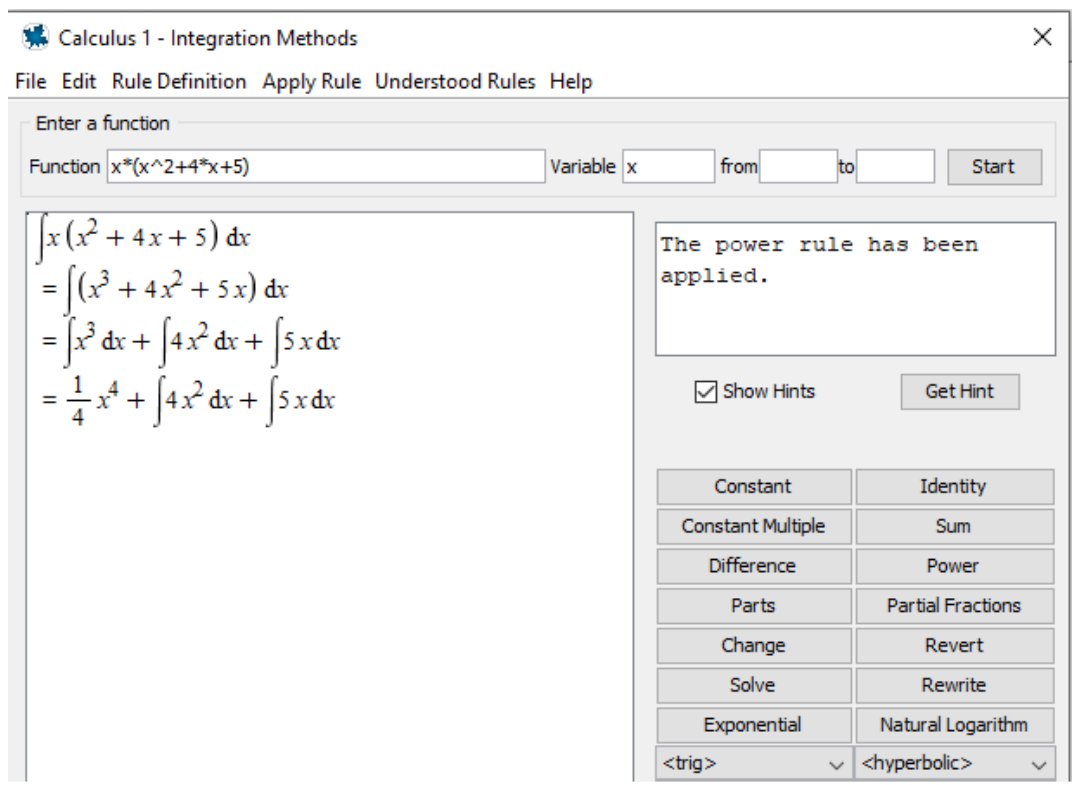

Gambar 4. tampilan hasil pencarian integral $f(x)=x\left(x^{2}+4 x+5\right)$ per langkah

Contoh-contoh tersebut di atas merupakan salah satu contoh untuk fungsi yang dapat dikatakan cukup mudah untuk dicari nilai integralnya. Sedangkan untuk fungsi-fungsi yang cukup sulit dalam mencari nilai integralnya atau yang memerlukan metode tertentu dalam pencariannya, maple juga dapat melakukan hal tersebut. Pada Gambar 5 diperlihatkan contoh fungsi yang dalam pencarian nilai integralnya diperlukan metode tertentu.

Calculus 1 - Integration Methods

File Edit Rule Definition Apply Rule Understood Rules Help

Enter a function

Function $\left(\operatorname{sqrt}\left(x^{\wedge} 3\right)\right)+(2 *$ sqrt $(x))+6$

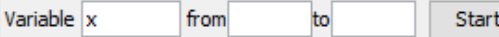

$\int\left(\left(\left(x^{3}\right)\right)^{\frac{1}{2}}+2 \sqrt{x}+6\right) d x$

$=\int\left(x^{\frac{3}{2}}+2 \sqrt{x}+6\right) \mathrm{d} x$

$=\int x^{\frac{3}{2}} \mathrm{~d} x+\int 2 \sqrt{x} \mathrm{~d} x+6 x$

$=\int 2 u^{4} \mathrm{~d} u+\int 2 \sqrt{x} \mathrm{~d} x+6 x$

$=2 \int u^{4} \mathrm{~d} u+\int 2 \sqrt{x} \mathrm{~d} x+6 x$

$=\frac{2}{5} u^{5}+\int 2 \sqrt{x} \mathrm{~d} x+6 x$

$=\frac{2}{5} x^{\frac{5}{2}}+\int 2 \sqrt{x} \mathrm{~d} x+6 x$

$=\frac{2}{5} x^{\frac{5}{2}}+2 \int \sqrt{x} \mathrm{~d} x+6 x$

$=\frac{2}{5} x^{\frac{5}{2}}+2 \int 2 u^{2} \mathrm{~d} u+6 x$

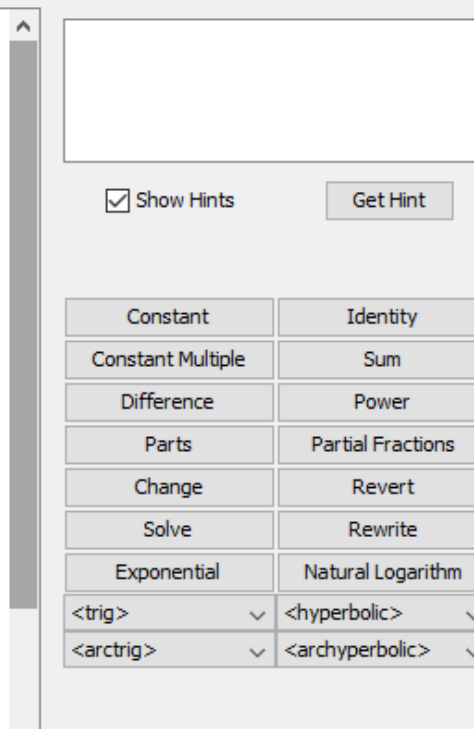




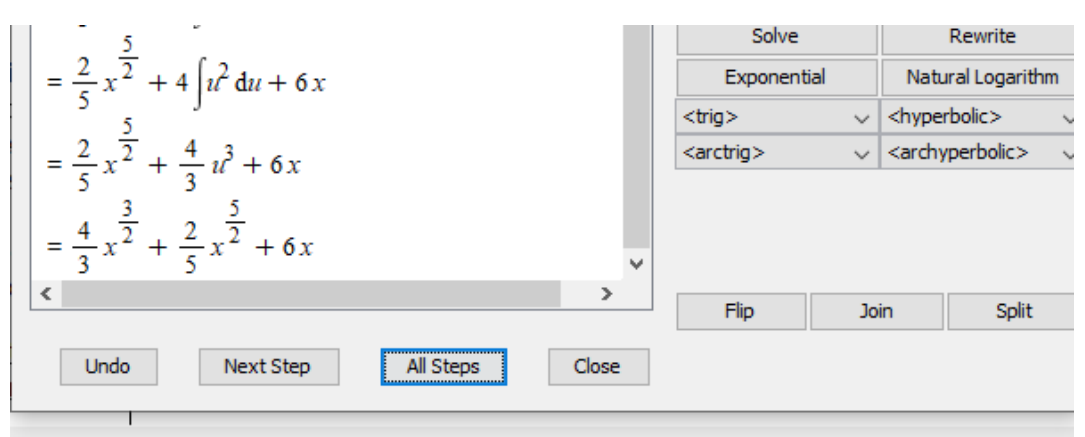

Gambar 5. Pencarian integral dari fungsi dengan menggunakan pemisalan

Dari gambar di atas terlihat bahwa bahkan pengerjaan setiap langkahnya detil. Bahkan rasanya seperti dijelaskan oleh seorang tutor asli. Tidak hanya itu, bahkan untuk fungsi-fungsi trigonometri pun, maple dapat mencari integralnya. Gambar berikut ini memperlihatkan hal tersebut..

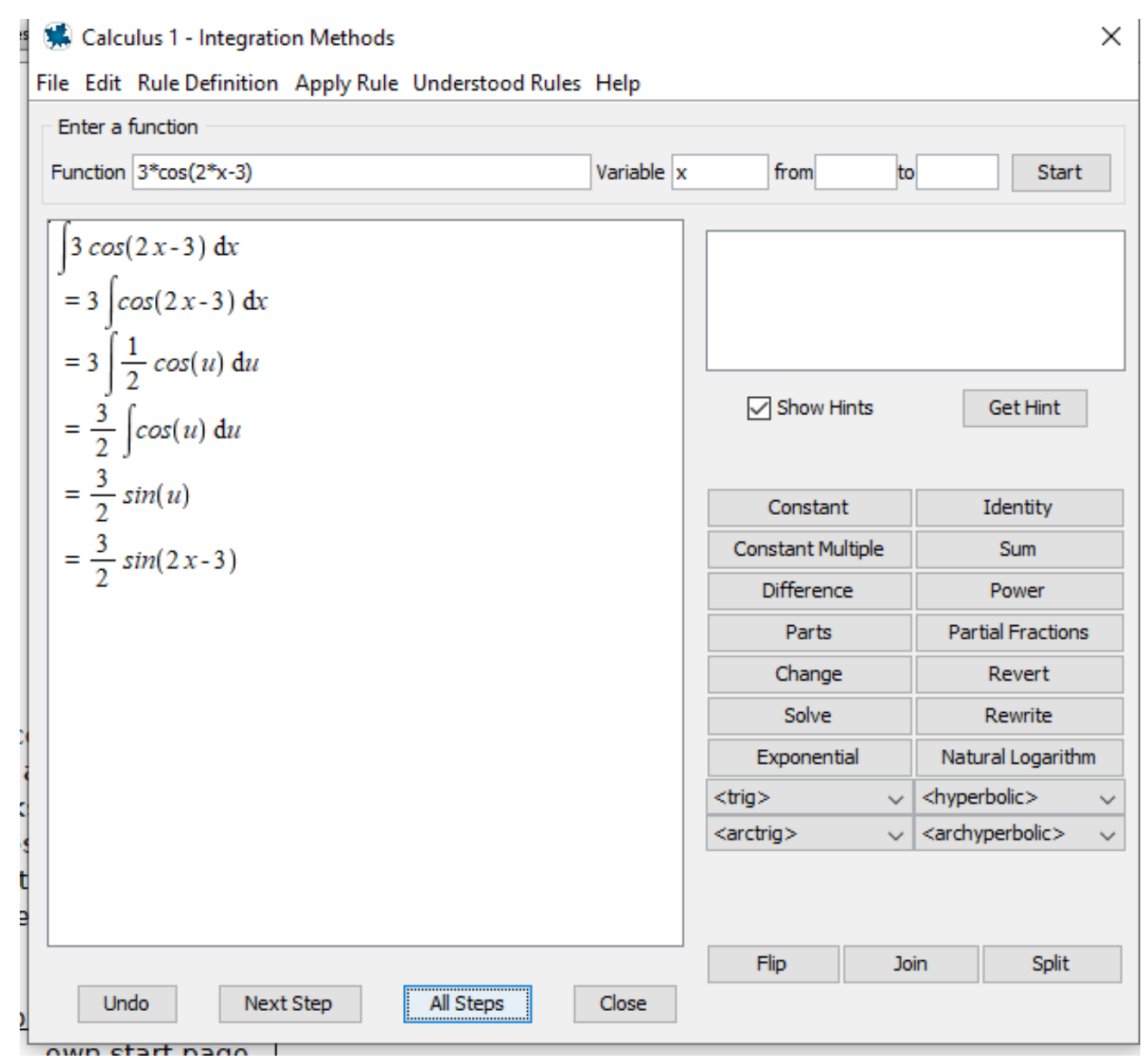

Gambar 6. tampilan hasil pencarian integral untuk fungsi trigonometri

Gambar berikut ini menunjukkan contoh untuk fungsi sedikit lebih rumit daripada fungsi-fungsi sebelumnya. 


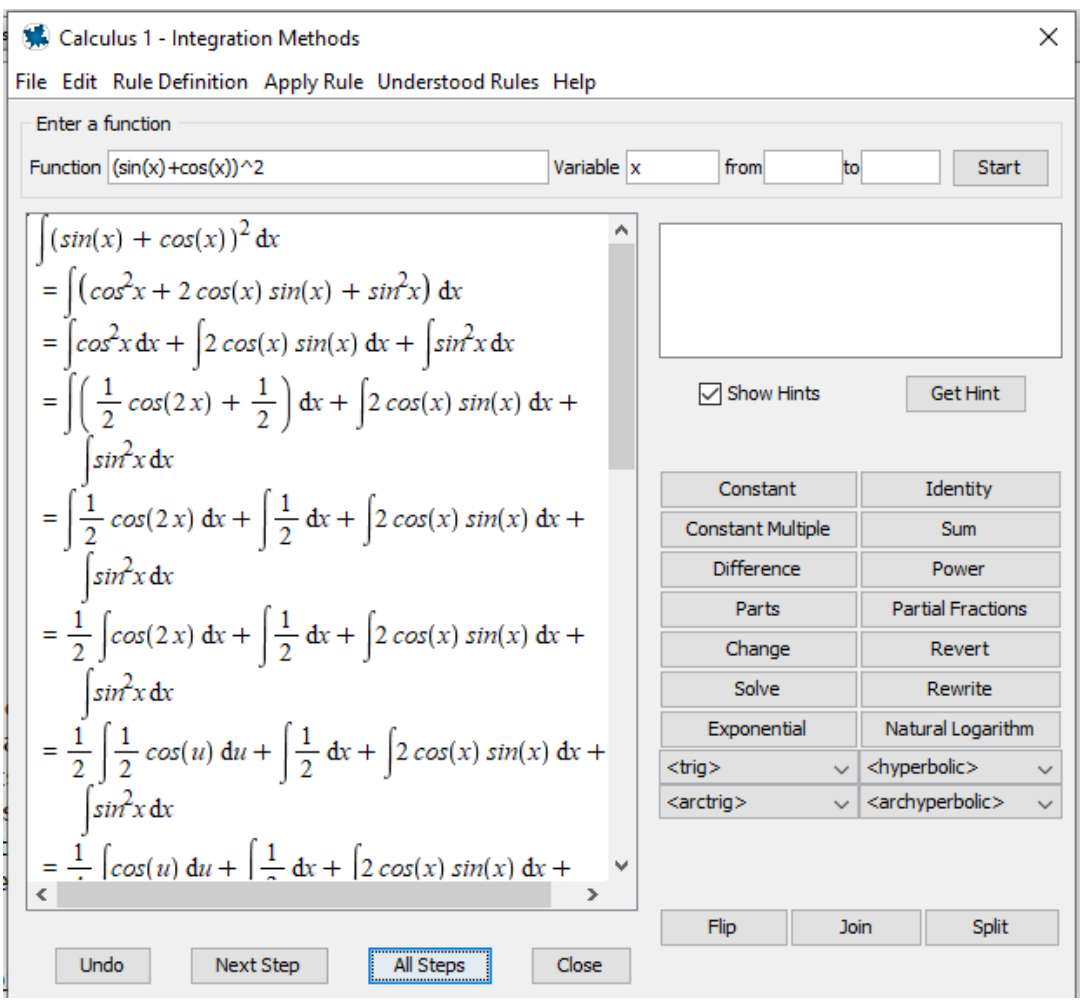

Gambar 7. tampilan hasil pencarian integral untuk fungsi trigonometri yang lebih rumit

Gambar- gambar di atas menunjukkan cara pencarian integral tak tentu dari suatu fungsi. Sedangkan untuk pencarian integral tentu, cukup denngan mengisi kotak "from" dengan nilai batas bawahnya dan kotak "to" untuk nilai batas atasnya. Untuk lebih jelasnya, perhatikan gambar berikut ini.

4. Calculus 1 - Integration Methods

File Edit Rule Definition Apply Rule Understood Rules Help

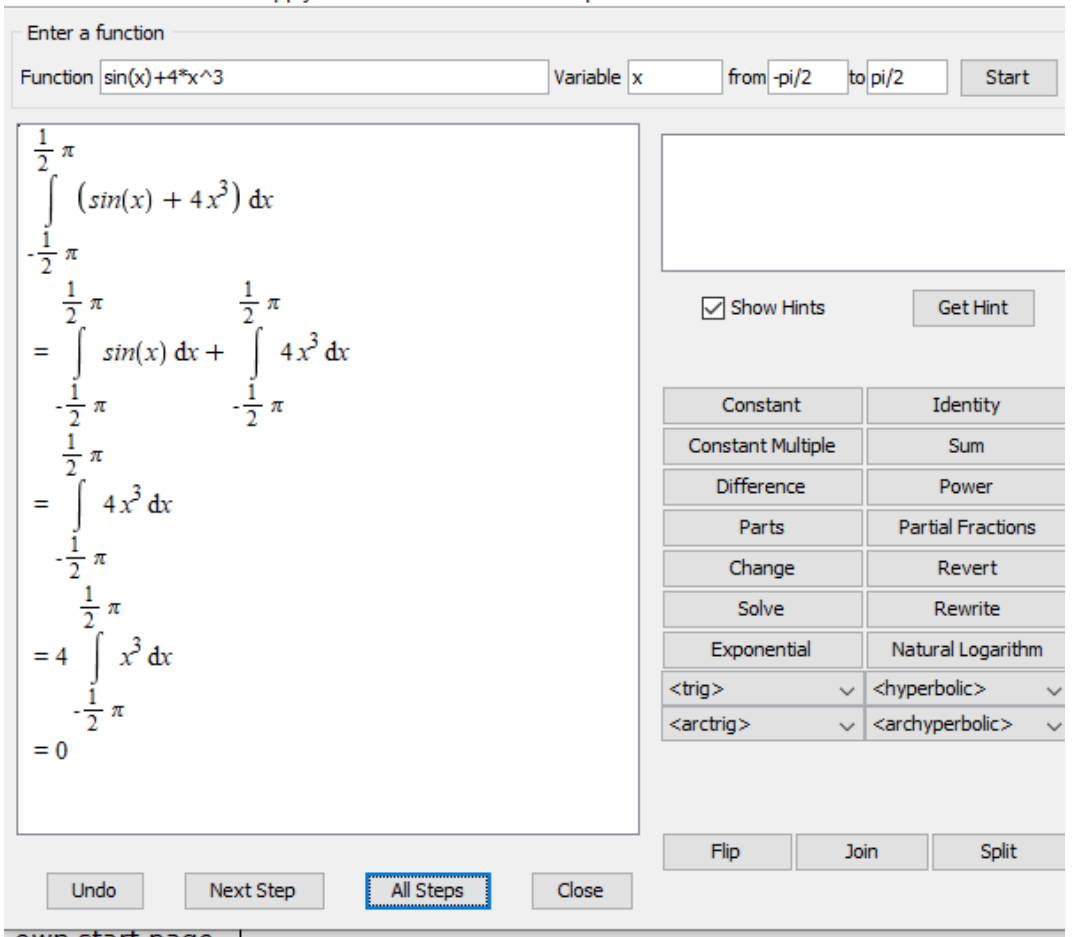

Gambar 8. tampilan hasil pencarian integral tentu untuk fungsi trigonometri

Gambar di bawah ini menunjukkan pencarian Integral Siklometri. 


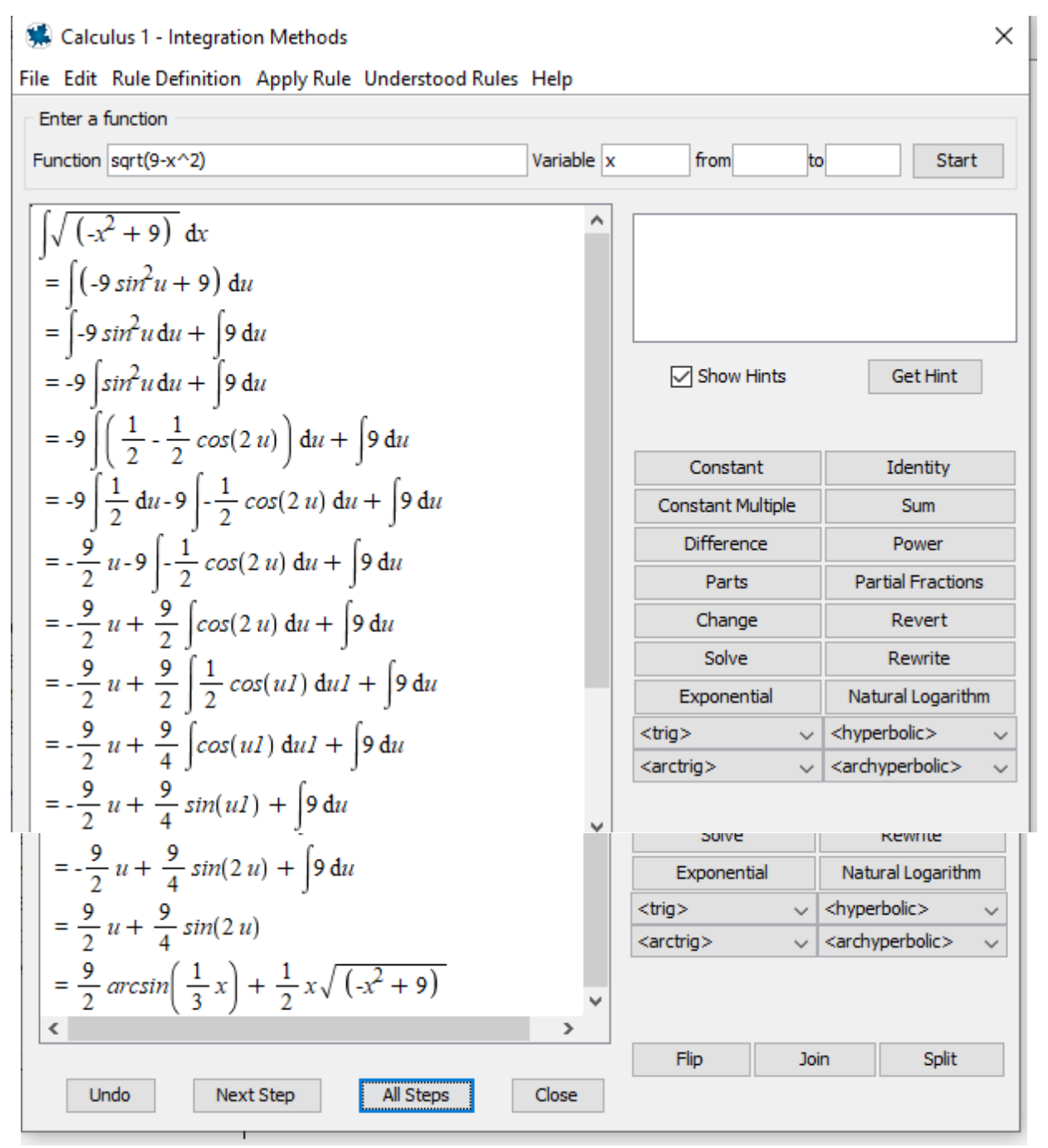

Gambar 9. tampilan hasil pencarian integral siklometri

Selain dari pencarian integral dari suatu fungsi, dengan menggunakan maple, siswa juga dapat diajak untuk memperkenalkan aplikasi dari integral. Misalnya saja bagaimana konsep mencari perkiraan volume. Langkah-langkahnya secara garis besar dapat dilihat pada Gambar 10 hingga Gambar 14 di bawah ini. Dengan menggunakan visualisasi siswa yang sebelumnya hanya mengenal konsep integral untuk mencari volume secara abstrak, kini dapat melihat gambarannya secara nyata. Visualisasi yang disajikan oleh maple juga tidak membuat mata bosan untuk melihatnya. Dengan demikian hal tersebut dapat menimbulkan ketertarikan siswa terhadap konsep integral. Siswa yang pada awalnya mungkin hanya tahu dengan menghapal rumus bagaimana mencari volume dengan menggunakan integral, kini dapat melihat visualisasi bagaimana sebenarnya konsep rumus tersebut bekerja. Dengan adanya media pembelajaran ini, diharapkan siswa tidak hanya hapal rumul integral, tetapi juga benar-benar memahami bagaimana konsep integral. 


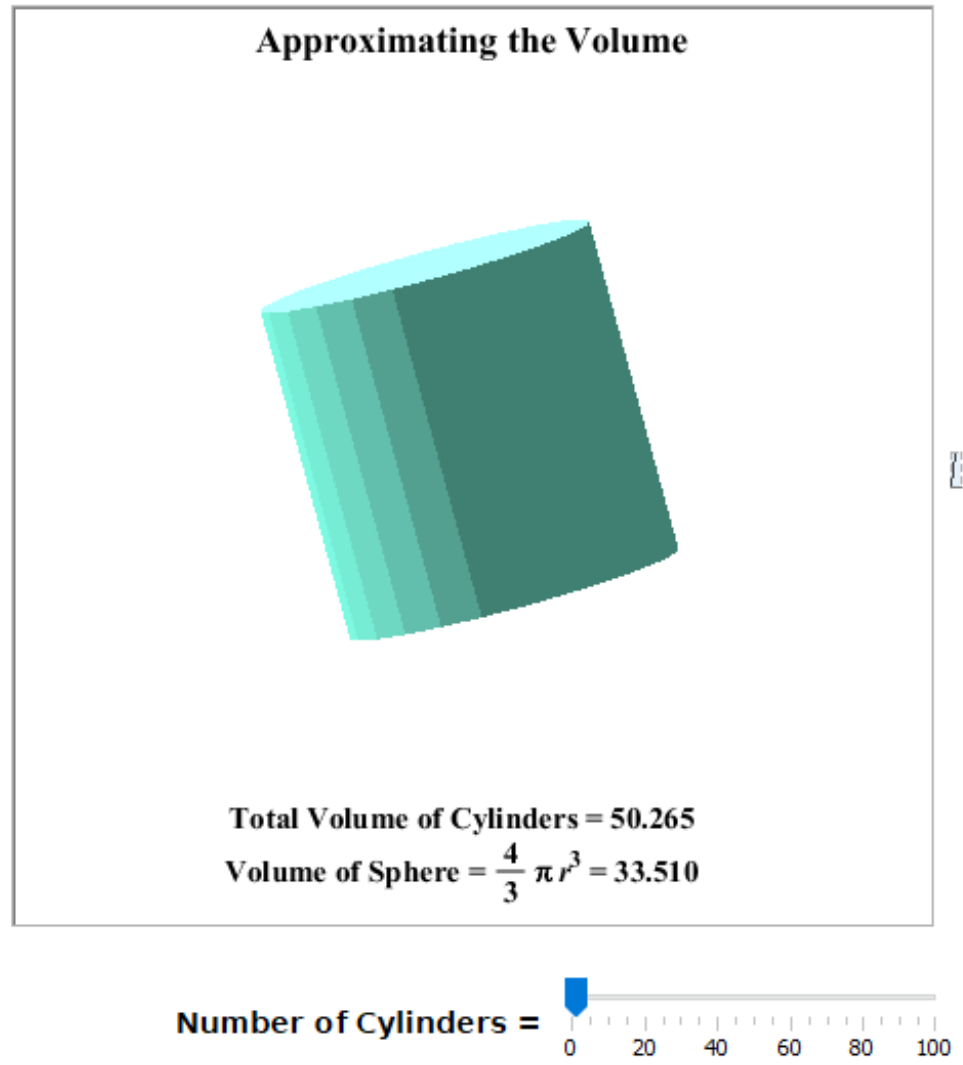

Gambar 10. Langkah 1 visualisasi pencarian volume dengan menggunakan integral

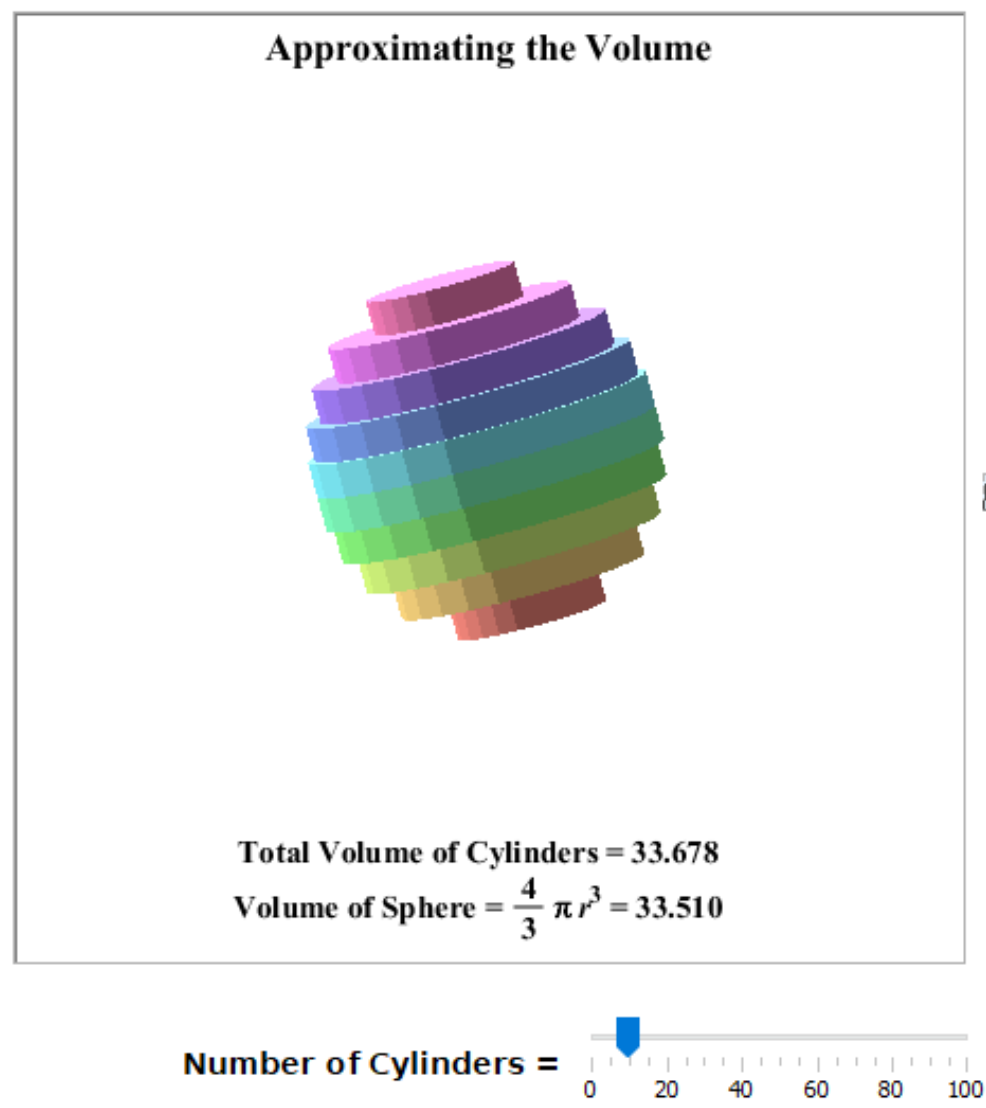

Gambar 11. Langkah 2 visualisasi pencarian volume dengan menggunakan integral 


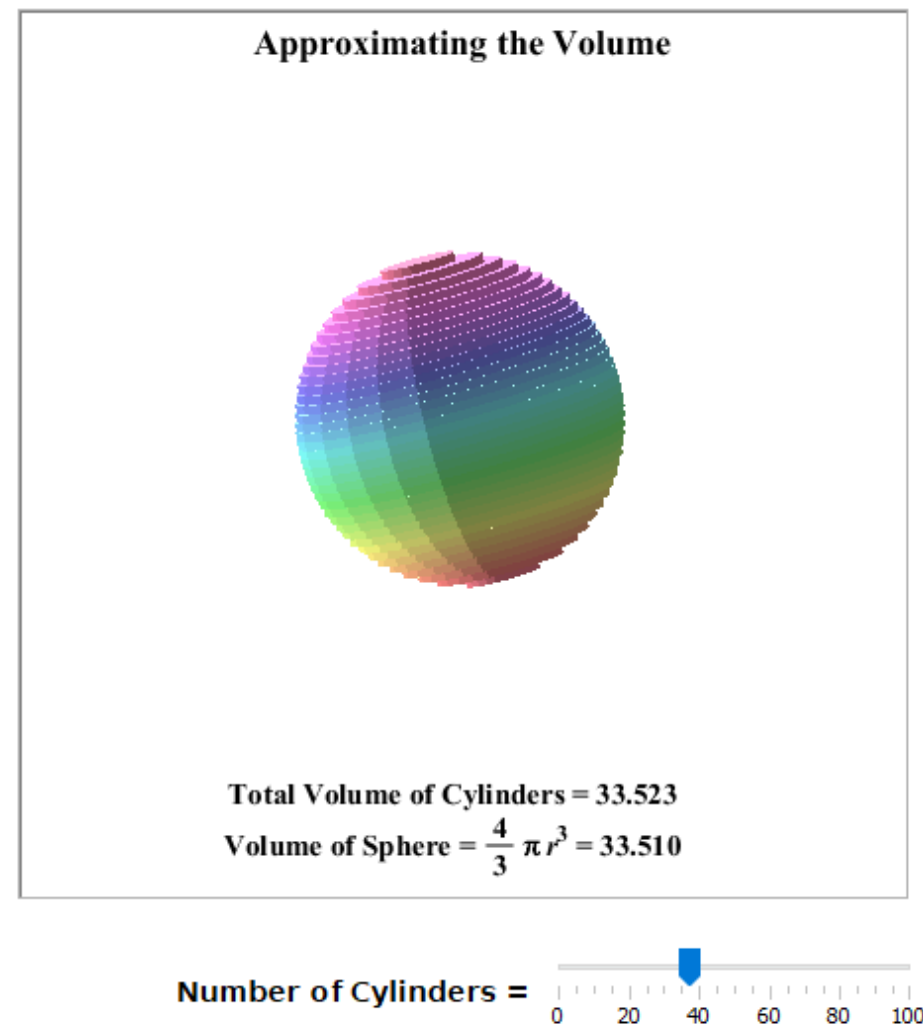

Gambar 12. Langkah 3 visualisasi pencarian volume dengan menggunakan integral

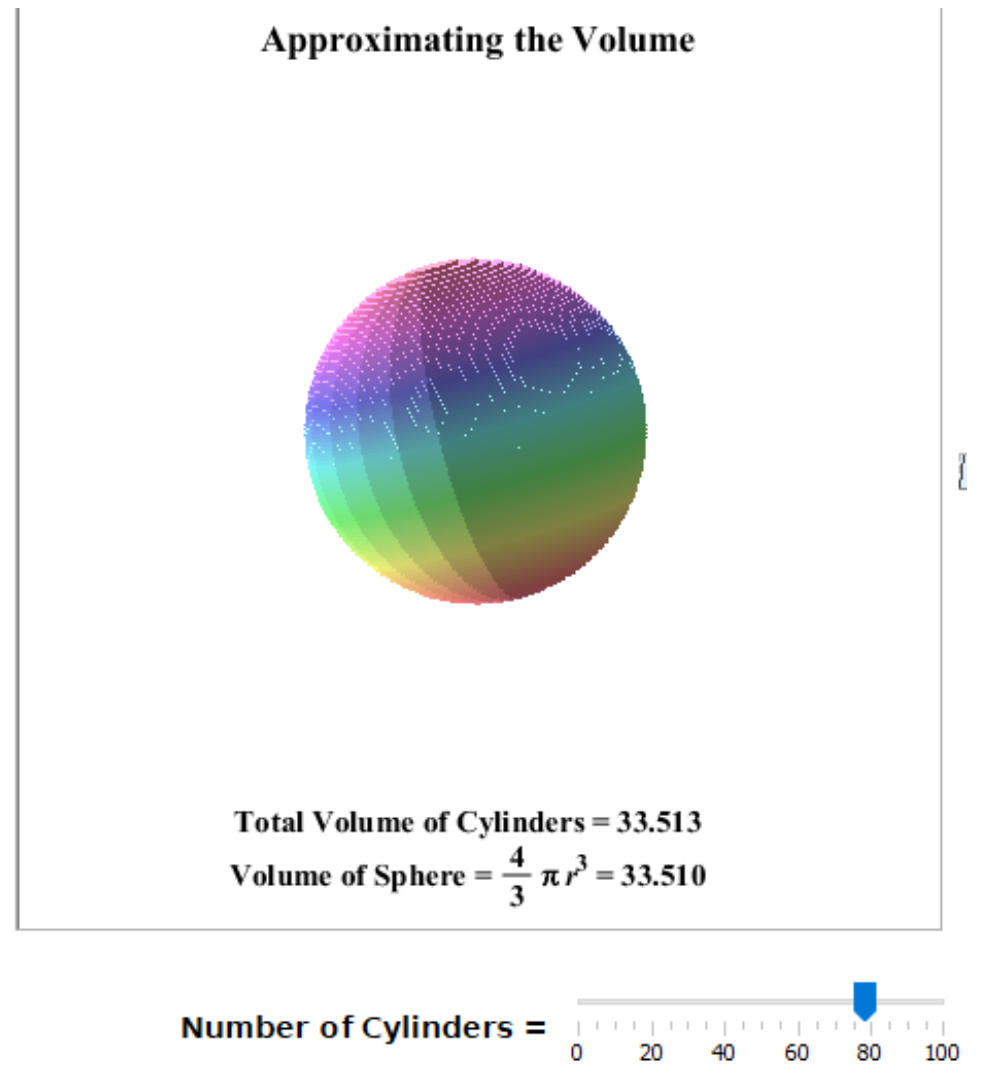

Gambar 13. Langkah 4 visualisasi pencarian volume dengan menggunakan integral 


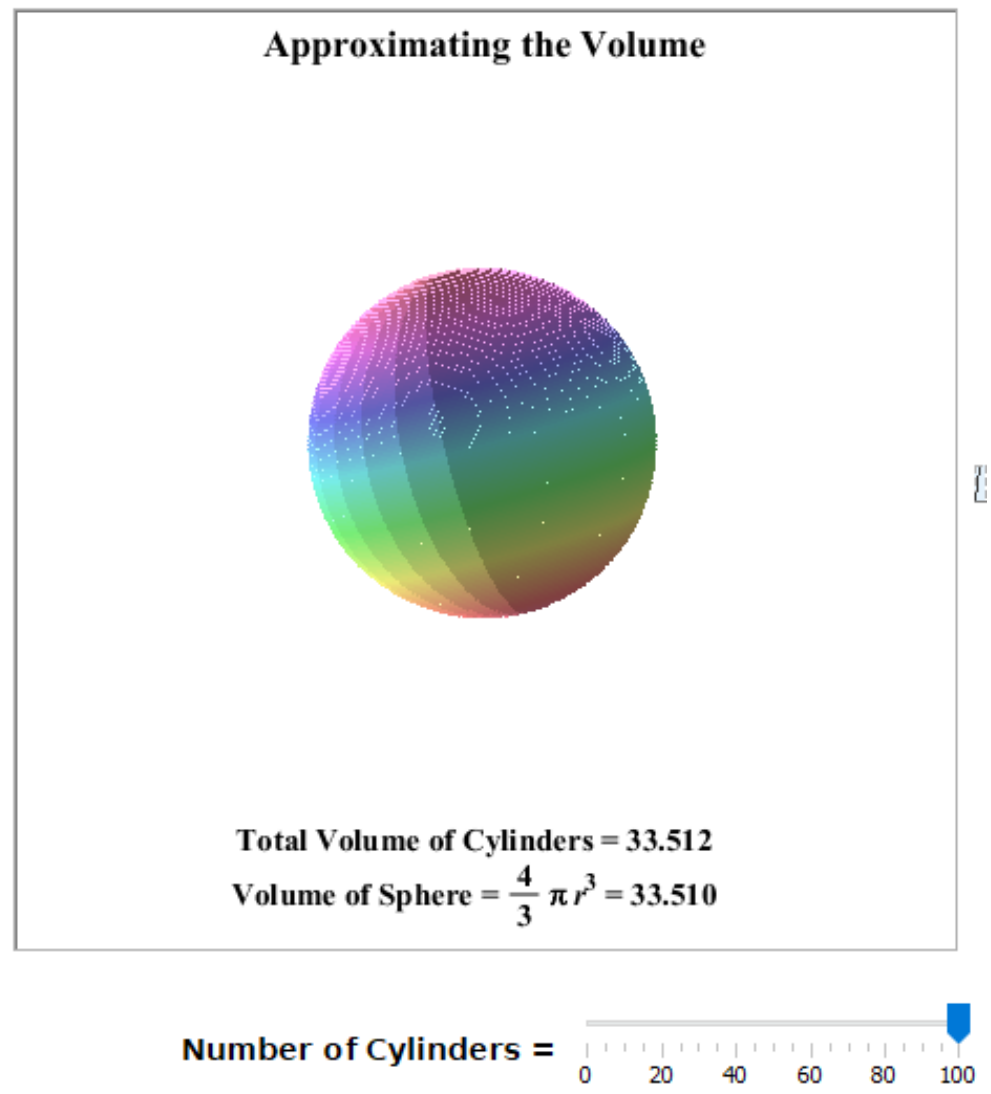

Gambar 14. Langkah 5 visualisasi pencarian volume dengan menggunakan integral

\section{Simpulan}

Telah diperlihatkan bagaimana maple dapat menjadi salah satu media pembelajaran matematika, khususnya untuk konsep integral. Materi tersebut sering dianggap sulit oleh kebanyakan siswa. Dengan menggunakan Maple, siswa dapat dengan mudah melihat langkah-langkah pencarian integral dari suatu fungsi dengan cara yang tidak membosankan. Siswa juga dapat melihat visualisasi dari aplikasi integral dengan visualisasi yang menarik. Hal tersebut diharapkan dapat meningkatkan daya tarik serta minat siswa dalam pembelajaran konsep integral. Pada akhirnya, dengan meningkatnya daya Tarik siswa, tingkat pemahamannya pun dapat meningkat.

\section{Daftar Pustaka}

1. F.C. Permana, AC Padmasari, S. Sylviani, Rancang Bangun Aplikasi Pendeteksi Jenis Golongan Darah Berdasarkan Konsep Kepercayaan Rakyat Jepang (Minkan Shinkō), Edsence: Jurnal Pendidikan Multimedia 1 (1), 25-34, 2019

2. Maplesoft. [Online]. Available: http://www.maplesoft.com

3. Xu, Hui, "Using Mathematical Software in High School Math Class:A Case Study". International Journal of Information and Education Technology, Vol. 6, No. 12, December 2016T. M. Wasfy, "Lea: Software system for multimedia and virtual-reality web-based education and training," presented at ASME International Design Engineering Technical Conferences and Computers and Information In Engineering Conference, DETC2006, Philadelphia, PA, United States, September 10-13, 2006.

4. M. A. Abánades, F. Botana, J. Escribano, and J. L. Valcarce, "Using free open source software for intelligent geometric computing," presented at 2011 International Conference on Computational Science and Its Applications, ICCSA 2011, Santander, Spain, June 20-21, 2011.

5. V. Thakkar, A. Shah, M. Thakkar, A. Joshi, and N. Mendjoge, "Learning math using gesture," presented at 2012 International Conference on Education and e-Learning Innovations, Sousse, Tunisia, July 1-3, 2012. 